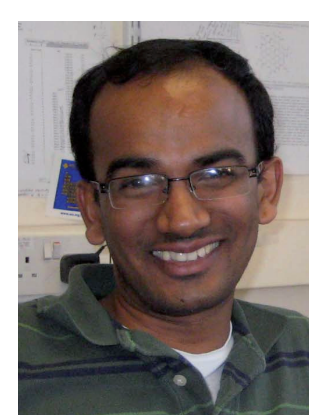

\section{Sadagopan Krishnan}

\section{Position}

Postdoctoral research associate

PhD

Chemistry

Research area

Enzyme-based biofuel cells

Inorganic Chemistry Laboratory, South Parks Road, Oxford, OXI 3QR, UK

Tel.: +441865282621

Fax: +44 1865287182

E-mail: sadagopan.krishnan@chem.ox.ac.uk in Analytical Chemistry on this that was featured on the cover. He also investigated fundamental properties of human metabolic cytochrome P450s - research was carried out at his own initiative, and explains for the first time the role of iron spin state on enzyme electron transfer rates. He then developed thin films that mimic the natural cytochrome P450 redox cycle for the first time. He worked with several other group members to develop a superparamagnetic labeling scheme for immunosensing of proteins by surface plasmon resonance at unprecedented low levels, down to $10 \mathrm{fg} / \mathrm{ml}$. Sadagopan has also demonstrated strong leadership skills. After his PhD, Sadagopan joined the group of Fraser Armstrong at Oxford University, UK, as a postdoctoral fellow. He is currently expanding his research horizons into the area of biofuel cells. His eventual goal is to join the faculty of a major university and build a world-class research group in bioanalytical chemistry.

Nominated by: James F Rusling, Department of Chemistry, University of Connecticut, 55 N. Eagleville Road, Storrs, CT 06269, USA Tel.: +| 860486 4909; Fax: + I 860486 298I; E-mail:james.rusling@uconn.edu

What drove you to choose a career in bioanalysis?

I want to pursue a research career related to human health and environmental protection. We all know that enzymes are the vital biomolecules in every form of life. So when I got admission for a PhD program at the University of Connecticut, I was fascinated by the research objectives of James Rusling. They involve bioanalytical methods for cancer biomarker detection, drug/pollutant toxicity screening using enzyme electrochemical arrays, redox mechanisms and biocatalysis of drug metabolizing enzymes. These objectives matched my interests perfectly and, thus, I chose to do my research career in bioanalysis.

Describe the main highlights of your bioanalytical research \& its importance to the bioanalytical community both now \& in the future

My bioanalytical research has led to the first demonstration of an ultrasensitive optical immunosensor utilizing magnetic particle-antibodyantigen bioconjugates for cancer biomarker detection. These immunosensors are promising for early point-of-care cancer diagnosis, well before the start of tumor formation. Hence, treatment becomes much easier without surgery being necessary. This is an important outcome for our society, as cancer is the major cause of death worldwide. My other bioanalytical research involves the development of high-throughput electrochemiluminescent (ECL) arrays for drug toxicity screening utilizing layer-by-layer films of cytochrome P450s, DNA and a ruthenium polymer electrocatalyst that can provide light by electrochemiluminescence. These simple, cost effective, molecular-based ECL arrays can complement existing bioassays to increase the assessment, and hence, the redesigning of a toxic drug in development. Furthermore, an extension of my research has led to the development of bioelectronic films consisting of microsomal reductase and excess cytochrome P450s on electrodes that efficiently mimic the natural cytochrome P450 catalytic pathway. This method has great potential for drug metabolism screening, biosensing applications and fundamental investigations of enzyme catalysis. Currently, in my

\section{FUTURE SCIENCE}


postdoctoral research, I am aiming to develop robust and high-performance enzyme fuel cells for portable microdevices using conductive high surface area biocatalyst electrodes.

Where do you see your career in bioanalysis taking you?

For my long-term career, I want to explore the field of bioanalytical applications especially for drug development, disease diagnosis and renewable energy. I see that my career in bioanalysis has already enabled me to develop simple, cost effective and reliable bioanalytical methods for applications in biomedical, pharmaceutical and energy-related fields. I wish to extend this direction by securing an academic position in a major research university in the US or UK. I feel it necessary to mention here that my long-term vision towards bioanalytical research and willingness to bring its applications to our society would not have happened without my advisors James Rusling and Fraser Armstrong.

How do you envisage the field of bioanalysis evolving in the future?

I envision that the bioanalysis field is going to make a big impact on human life and on the world economy in the 21 st century. Since bioanalysis has applications worldwide and in every part of our life, it has the potential to revolutionize certain areas of endeavor. In particular, drug discovery and development, point-of-care medical diagnostics, green chemistry and renewable energy should all greatly benefit from advanced bioanalytical devices and protocols. The emerging power of cheap bioanalytical arrays that could be implemented in simple platforms with low-power sources, such as biofuel cells or cell phones, should have a great impact on these areas in the future. Each level of success in this area of research and development is going to help create a more healthy and productive world. Considering these facts, much more focus, support and investment are needed from governments and research agencies on bioanalysis.

\section{Financial \& competing interests disclosure}

The author has no relevant affiliations or financial involvement with any organization or entity with a financial interest in or financial conflict with the subject matter or materials discussed in the manuscript. This includes employment, consultancies, honoraria, stock ownership or options, expert testimony, grants or patents received or pending, or royalties.

No writing assistance was utilized in the production of this manuscript.

\section{Representative publications}

- Krishnan S, Mani V, Wasalathanthri D, Kumar CV, Rusling JF. Attomolar detection of a protein biomarker in serum by surface plasmon resonance using superparamagnetic particle labels. Angew. Chem. Int. Ed. 50, 1175-1178 (2011).

- Krishnan S, Wasalathanthri D, Zhao L, Schenkman JB, Rusling JF. Efficient bioelectronic actuation of the natural catalytic pathway of human metabolic cytochrome P450s. J. Am. Chem. Soc. 133, 1459-1465 (2011).
- Krishnan S, Abeykoon A, Schenkman JB, Rusling JF. Control of electrochemical and ferryloxy formation kinetics of cyt P450s in polyion films by heme iron spin state and secondary structure. J. Am. Chem. Soc. 131, 16215-16224 (2009).

- Krishnan S, Hvastkovs EG, Bajrami B, Choudhary D, Schenkman JB, Rusling JF. Synergistic metabolic toxicity screening using
microsome/DNA electrochemiluminescent arrays and nanoreactors. Anal. Chem. 80, 5279-5285 (2008).

- Krishnan S, Hvastkovs EG, Bajrami B, Jansson I, Schenkman JB, Rusling JF. Genotoxicity screening for $N$-nitroso compounds by electrochemical and electrochemiluminescent detection of human enzyme-generated DNA damage. Chem. Commun. 7(17), 1713-1715 (2007).

\section{Waters}

\section{Bioanalysis Young Investigator Award - sponsored by Waters THE SCIENCE OF WHAT'S POSSIBLET'}

Each issue of Bioanalysis features a Young Investigator profile, where young bioanalysts have the opportunity to describe their work and future aspirations. At the end of each year a winner will be selected by the editorial advisory board and will be presented with a \$1000 award, sponsored by Waters. A travel fund is provided by Waters to assist with the cost of travel to the award ceremony.

For a young scientist, being recognized for your hard work at such an early stage in your career is a tremendous honor.

Young Investigators should be early career researchers, including Masters and Doctorate students, Postdoctorate researchers and those working in industry.
If you wish to nominate a Young Investigator, please contact the Editor for more details.

Ryan De Vooght-Johnson,

Junior Managing Commissioning Editor

Future Science Ltd,

Unitec House,

2 Albert Place,

London, N3 IQB, UK

Tel.: +44 (0)20 837I 6090

Fax: +44 (0)20 83432313

E-mail: r.devooght-johnson@future-science.com 